Egypt. J. of Nutrition and Health Vol. 10 No. 1 (2015)

\title{
Potential therapeutic impacts of phyllanthus and costus aqueous extracts on CcL4 intoxicated rats
}

\author{
Mona E.M. Naga' and El-Sayed H. Bakr ${ }^{2,3}$ \\ ${ }^{1}$ Home Economics Department, Faculty of Specific Education, Minufiya University, Egypt \\ ${ }^{2}$ Nutrition and Food Science Department, Faculty of Home Economics, Minufiya \\ University, Egypt. \\ ${ }^{3}$ Clinical Nutrition Department, Faculty of Applied Medical Sciences, Umm Al-Qura \\ University, KSA.
}

\begin{abstract}
Bakground: Chronic liver damage is a worldwide common pathology, characterised by an inflammatory and fibrotic process that leads to a progressive evolution from chronic hepatitis to cirrhosis and hepatocellular carcinoma. A major role of fats and oxidative stress has been recently demonstrated in the pathogenesis of liver diseases. It was a newly introduced plant from Mexico. In India, it is grown in gardens, especially in Kerala, where the fresh leaves are eaten raw by diabetic people Objective: This work aimed to study the effect of phyllanthus and costus aqueous extracts on CcL4 intoxicated rats. Material and methods: Thiry mature male albino rats weighing $150 \pm 5 \mathrm{~g}$ were obtained from Laboratory of Animal Colony, Helwan, Egypt. Rats were divided into 6 equal groups ( $n=5$ rats each); one group was kept as a control negative, while the other 5 groups were injected subcutancosly (s/c) by carbon tetrachloride (CcL4) in parrafin oil $50 \% \mathrm{VN}(2 \mathrm{ml} / \mathrm{kg}$ b.wt.) twice a week for two weeks for liver intoxication then, one group of them was left as control positive group $(\mathrm{C}+\mathrm{ve})$ while the rest four groups were given orally two doses $(250$ and $500 \mathrm{mg} / \mathrm{kg})$ of phyllanthus and costus aqueous extracts $(250 \mathrm{mg} / \mathrm{kg}$ and $500 \mathrm{mg} / \mathrm{kg}$ for the group. At the end of experimental period (45 days), blood samples were collected for serum separation to determine serum liver enzymes (AST, ALT and ALP), total cholesterol, triglycerides, atherosclerosis index, lipoprotein fraction (HDLC, LDLC and VLDLC), kidney function(Creatinine, Urea and Uric acid) and histopathological examination for the liver. Results: The obtained results demonstrated that phyllanthus and costus aqueous extracts caused significant improvement in liver enzymes, lipid profiles and kidney functions in CCL4 intoxicated rats. Conclusion: According to the results, phyllanthus and costus aqueous extracts could be tried on intoxicated patieats to improve liver \&kidney function
\end{abstract}

Keywords: Liver intoxication, phyllanthus, costus, aqueous extracts.

\section{Introduction}

Chronic liver damage is a worldwide common pathology, characterised by an inflammatory and fibrotic process that leads to a progressive evolution from chronic hepatitis to cirrhosis and hepatocellular carcinoma. A major role of fats and oxidative stress has been recently demonstrated in the pathogenesis of liver diseases. (Filomena et al., 2008) 
Phyllanthus emblica Linn. is widely used in Thai traditional medicine for treatment of various diseases. P. emblica is known as a rich source of vitamin $\mathrm{C}$, and also contains a mixture of phenolic compounds. Moreover, $\mathrm{P}$. emblica is a potential source of natural antioxidants, which have free radical scavenging activity and might be useful for hepato-, cyto-, and radio-protection, as well as reducing oxidative stress in many pathological conditions. (Charoenteeraboon et al., 2010). It was a newly introduced plant from Mexico. In India, it is grown in gardens, especially in Kerala, where the fresh leaves are eaten raw by diabetic people. (Jayasri, et al., 2009).

Phytochemical composition of costus extract and its alleviation of carbon tetrachloride-induced hepatic oxidative stress and toxicity were evaluated. The qualitative and quantitative analyses showed the presence of alkaloids, saponins, flavonoids, tannins and phenols in the aqueous stem extract while flavonoids, saponins and phenols were detected in the ethanol extract. Moreover, biological active compounds of costus are more polar and could serve as source of bioactive compounds for nutrition and therapeutic purposes. (Ukpabi et al., 2012).

This work aimed to study the Potential therapeutic impacts of phyllanthus and costus aqueous extracts on rats injected with carbon tetrachloride(CcL4).

\section{Materials and Methods}

\section{1- MATERIALS}

1.1. Plants: The tested plants in this investigation were phyllanthus and costus and they were bought from local market. 1.2. Rats: Thirty mature male albino rats weighing $150 \pm 5$ g. b.wt. were obtained from Laboratory of Animal Colony, Helwan, Egypt.

1.3. Basal diet: Basal diet consisted of casein (12.5\%), corn oil $(10 \%)$, choline chloride $(0.2 \%)$, vitamin mixture $(1 \%)$ (Campbell, 1963), cellulose (5\%), salt mixture (4\%), sucrose $(22 \%)$ and corn starch (up to $100 \%$ ) according to the method described by Hegsted et al., (1941)

1.4. Carbon tetra chloride (CcL4): Carbon tetrachloride ( $C L L 4)$ was obtained from El-Gomhoryia Company for Chemical Industries, Cairo, Egypt as $10 \%$ liquid solution. It was dispensed in white plastic bottles each containing one liter as a toxic chemical material for liver poisoning according to Passmore and Eastwood (1986).

\section{2- METHODS}

\subsection{Preparation of plant aqueous extracts:}

The plant is availaple in Egyption market and purchased, milling, and dryingm, for use in research . One gram of powdered phyllanthus or costus mixed with $100 \mathrm{ml}$ distilled water were boiled for 10 min and then cooled for 15 min. Thereafter, the aqueous extract was filtered using a Millipore filter (Millipore $0.2 \mathrm{~mm}$, St. Quentin en Yvelines, France) to remove particulate matter. The filtrate was then freeze-dried and the desired dose (250 and $500 \mathrm{mg}$ of lyophilized aqueous extract of phyllanthus and costus per $\mathrm{kg}$ body weight of the rat) was then prepared and reconstituted in $1.5 \mathrm{ml}$ of distilled water. The aqueous extracts were prepared daily, just before administration. The extracts obtained were then given orally to different groups of rats at a dose of 250 and $500 \mathrm{mg} / \mathrm{kg}$ body weight. (Lemhadri et al., 2004).

\subsection{Experimental design:}

All the experiment process was done in Ophthalmology Hospital, Giza. Thirty Sprague-Dawley male albino rats, each weighing $150 \pm 5 \mathrm{~g}$., were housed in special cages under controlled conditions. Every day, animals were observed for the external appearance, shape, colour and distribution of hair and physical activity. All rats were fed on basal diet for 7 consecutive days before the beginning of the experiment for adaptation. Diets were presented to rats in 


\section{Egypt. J. of Nutrition and Health Vol. 10 No. 1 (2015)}

special non-scattering feeding cups to avoid loss of food and contamination. Tap water was provided to rats by mean of glass tubes projecting through wire cages from inverted bottles supported to one side of the cage. Rats were divided into two main groups. The first main group ( $n=5$ rats) were fed on basal diet and left as a negative control group. The second main group injected s/c by carbon tetrachloride (CcL4) in parrafin oil $50 \% \mathrm{VN}(2 \mathrm{ml} / \mathrm{kg}$ b.wt.) twice a week for two weeks to induce chronic intoxication of the liver according to the method described by Jayasekhar et al., (1997), then they were divided into five equal groups ( $5 \times 5$ rats each), one of them was left as control positive group ( $\mathrm{C}+\mathrm{ve})$ while the rest four groups were orally given using two doses of 250 and $500 \mathrm{mg} / \mathrm{kg}$ of phyllanthus and costus aqueous extracts individually for each of them.

\subsection{Biological and biochemical Evaluation}

During the experimental period for each experimental part,the diet consumed was recorded every day, and body weight recorded every week. The body weight gain(BWG), feed efficiency ratio (FER), and also relative organ weight (ROW\%) were determinate according to Chapman et al.(1959) using the following equations.

BWG $=$ Final weight-Inital weight

FER $=\frac{\text { Body weight gain (g/day) }}{\text { Feed intake (g/day) }}$

ROW $\%=\frac{100 \times \text { Organ weight }}{\text { Total body weight }}$

At the end of experimental period (45 days),, blood samples were collected for serum separation to determine the following parameters: Serum liver enzymes(ALT, AST) according to Reitman and Frankel (1957) and ALP according to Roy (1970), total cholesterol according to Ratliff and Hall (1973), triglycerides according to Jacobs and Van-Denmark (1960), lipoprotein fractions (HDLc, LDLC and VLDLC) according to Gordon and Amer (1977).

Atherogenic index $(\mathrm{Al})=\frac{\mathrm{LDL}+\mathrm{VLDL}}{\mathrm{HDL}}$

Creatinine, urea and uric acid determined according to (Henry, 1974), (Pattn and Crouch, 1977) and (Schultz, 1984), respectively.

Liver was removed, cleaned in saline solution and dried then weighed. Liver was kept in formalin solution for histopathological examination according to Drury and Wallington (1967).

\subsection{Statistical analysis}

The obtained data were statistically analyzed using computerized SPSS (Statistic Program Sigma stat, statistical soft-ware, SAS Institute, Cary, NC). Effects of different treatments were analyzed by one way ANOVA (Analysis of variance) test using Duncan's multiple range test and $p<0.05$ was used to indicate significant difference between groups (Snedecor and Cochran, 1967).

\section{Results and Discussion}

1. Effect of the extracts on food intake (FI), body weight gain\% (BWG\%) and feed efficiency ratio (FER)

Food intake ( $\mathrm{FI})$ the $(\mathrm{C}+\mathrm{ve})$ group was $21.40 \pm 2.80 \mathrm{~g} /$ day compared to $23.70 \pm 1.60 \mathrm{~g} / \mathrm{day}$ in (C -ve) normal rats. This result denotes significant decrease in $\mathrm{Fl}$ of rats intoxicated with $\mathrm{CcL} 4(\mathrm{C}+\mathrm{ve})$ group as compared to (Cve)group. All rats poisoned by CCL4 and given phyllanthus and costus aqueous extract at both doses showed significant decrease in $\mathrm{FI}$ compared to both (C-ve) and (C+ve) group.

Data present in table (1) show the effect of phyllanthus and costus aqueous extracts on food intake (FI), body weight gain \% (BWG\%) and feed efficiency ratio (FER) of CcL4 - intoxicated rats. 
Table (1):

Effect of phyllanthus and costus aqueous extracts on FI (Food intake), BWG\%(Body weight gain) and FER (Feed efficiency ratio) of CcL4-intoxicated rats.

\begin{tabular}{|c|c|c|c|}
\hline Groups $\quad$ parameters & $\mathrm{FI}(\mathrm{g})$ & BWG(\%) & FER \\
\hline Control -ve & $23.70 \pm 1.60 \mathrm{a}$ & $35.00 \pm 5.00 \mathrm{a}$ & $0.053 \pm 0.003 a$ \\
\hline Control+ve & $21.40 \pm 2.80 \mathrm{~b}$ & $15.00 \pm 3.00 \mathrm{~d}$ & $0.025 \pm 0.001 \mathrm{~b}$ \\
\hline Phyllanthus 250/mg/kg & $11.10 \pm 4.00 \mathrm{c}$ & $17.00 \pm 4.00 \mathrm{cb}$ & $0.055 \pm 0.006 a$ \\
\hline Phyllanthus 500/mg/kg & $14.10 \pm 3.00 \mathrm{c}$ & $22.00 \pm 4.00 \mathrm{~b}$ & $0.056 \pm 0.004 a$ \\
\hline Costus $250 / \mathrm{mg} / \mathrm{kg}$ & $11.90 \pm 2.10 \mathrm{c}$ & $18.00 \pm 2.00 \mathrm{bc}$ & $0.054 \pm 0.003 a$ \\
\hline Costus 500/mg/kg & $12.90 \pm 3.40 \mathrm{c}$ & $20.00 \pm 2.00 \mathrm{~b}$ & $0.055 \pm 0.001 \mathrm{a}$ \\
\hline
\end{tabular}

Values denote arithmetic means \pm Standard error of the mean.

Means with different letters $(a, b, c, d)$ in the same column differ significantly at $p \leq 0.05$ using one way ANOVA test, while those with similar letters denote non-significant difference.

It could be observed concerning body weight gain, that body weight gain\% (BWG\%) in (C -ve) group was $35.00 \pm 5.00 \%$ but in $(C+v e)$ group it was $15.00 \pm 3.00 \%$. The obtained results showed that there were significant decrease in BWG\% in CCL4-intoxicated rats when compared to the contoral negative group. All rats given phyllanthus and costus aqueous extract at both doses showed significant increase $p<0.05$ when compared to $(C+v e)$ group. However, there were non-significant changes between all treated groups.

Regarding feed efficiency ratio (FER), it was found from data of the same table that in rats injected with CcL4 without treatment $(C+v e)$ group, FER was $0.025 \pm 0.001$ while in $(C-v e)$ it was $0.053 \pm 0.003$. These results denote that there was a significant decrease in FER of rats poisoned by CCL4 as compared to (C-ve) rats. All rats poisoned by CCL4 and given with phyllanthus and costus aqueous extract at both doses had significant increase in (FER)as compared to control negative group while no significant changes when compared to control negative group.

Dickerson and Lee (1988) reported in their referances that many patients with acute or chronic liver disease are ill, and commonly lose weight.

\section{Biochemical analysis}

Tables from (2) to (5) show the effect of oral ingestion or phyllanthus and costus aqueous extracts on liver enzymes (AST, ALT and ALP), lipid profiles (total cholesterol, triglycerides, atherosclerosis index, HDL, LDL and VLDL) and kidney function( creatinine, urea and uric acid) of CCL4-intoxicated rats.

\subsection{Effect on liver enzymes (AST, $A L T$ and $A L P$ )}

Table (2) shows the effect of oral ingestion of phyllanthus and costus aqueous extracts on serum liver enzymes including aspartate amino transaminase (AST), alanine amino transferase (ALT) and alkaline phosphatase (ALP) enzymes on CCL4-intoxicated rats. 
Table (2):

Serum levels of aspartate amino transaminase (AST), alanine amino transferase (ALT) and alkaline phosphatase $(A L P)$ enzymes of CcL4-intoxicated and treated rats.

\begin{tabular}{|l|l|l|l|}
\hline \multicolumn{1}{|c|}{ parameters } & \multicolumn{1}{|c|}{ AST (U/L) } & \multicolumn{1}{c|}{ ALT (U/L) } & \multicolumn{1}{c|}{ ALP (U/L) } \\
\hline Control -ve & \multicolumn{1}{c|}{-ve } & & $93.30 \pm 2.10 \mathrm{e}$ \\
\hline Control+ve & $42.40 \pm 0.50 \mathrm{f}$ & $22.60 \pm 2.50 \mathrm{~d}$ & $185.20 \pm 6.10 \mathrm{a}$ \\
\hline Phyllanthus $250 / \mathrm{mg} / \mathrm{kg}$ & $59.40 \pm 330 \mathrm{e}$ & $63.10 \pm 2.70 \mathrm{a}$ & $123.50 \pm 3.10 \mathrm{c}$ \\
\hline Phyllanthus $500 / \mathrm{mg} / \mathrm{kg}$ & $85.10 \pm 1.80 \mathrm{c}$ & $28.20 \pm 1.70 \mathrm{c}$ & $113.10 \pm 3.80 \mathrm{~cd}$ \\
\hline Costus $250 / \mathrm{mg} / \mathrm{kg}$ & $94.50 \pm 3.20 \mathrm{~b}$ & $26.00 \pm 3.00 \mathrm{~cd}$ & $130.70 \pm 6.20 \mathrm{bc}$ \\
\hline Costus $500 / \mathrm{mg} / \mathrm{kg}$ & $93.80 \pm 30 \mathrm{~b}$ & $38.71 \pm 3.20 \mathrm{~b}$ & $135.40 \pm 6.10 \mathrm{~b}$ \\
\hline
\end{tabular}

Values denote arithmetic means \pm Standard error of the mean.

Means with different letters (a, b,c,d) in the same column differ significantly at $p \leq 0.05$ using one way ANOVA test, while those with similar letters denote non-significant difference.

From table (2) that in rats intoxicated with CcL4 without treatment, the serum levels of AST, ALT and ALP enzymes were $115.30 \pm 7.10,63.10 \pm 2.70$ and $185.20 \pm 6.10 \mathrm{U} / \mathrm{L}$, respectively, while in $(\mathrm{C}$-ve) rats, the serum levels of the mentioned previously enzymes were $42.40 \pm 0.50,22.60 \pm 2.50$ and $93.30 \pm 2.10 \mathrm{U} / \mathrm{L}$, respectively. These findings denote that there were significant increases of AST, ALT and ALP enzymes in the serum of rats poisoned by CcL4 as compared to $(\mathrm{C}-\mathrm{ve})$ normal rats ( $\mathrm{p}$ value). All rats poisoned by CCL4 and given phyllanthus and costus aqueous extract at both doses showed significant decrease( $p$ value) in serum levels of AST, ALT and ALP activities when compared to control positive group.

Moreover, Gulati et al., (1995) concluded that Phyllanthus emblica is a constituent of many hepatoprotective formulations available in india market. 50 fifty percent alcoholic extract of $P$. emblica and quercetin isolated from it were studied for hepatoprotective effect against country made liquor and paracetamol challenge in albino rats and mice respectively. The extract at the dose of $100 \mathrm{mg} / 100 \mathrm{~g}$ [corrected], and quercetin at the dose of 15 $\mathrm{mg} / 100 \mathrm{~g}$, po, produced significant hepatoprotection. Also, Sultana et al., (2005) studied the pretreatment with Emblica officinalis at doses of 100 and $200 \mathrm{mg} / \mathrm{kg}$ body weight, prior to CCl4 intoxication showed significant reduction in the levels of SGOT, SGPT, LDH, glutathione-S-transferase, LPO and DNA synthesis. There was also increase in reduced glutathione, glutathione peroxidase and glutathione reductase. Their results suggest that $\mathrm{E}$. officinalis inhibits hepatic toxicity in Wistar rats.

Meanwhile, Eliza et al., (2009) reported that Costus speciosus could alter plasma enzyme (aspartate aminotransferase, alanine aminotransferase, lactate dehydrogenase, alkaline phosphatase and acid phosphatase) levels to near normal. Results of their experimental study indicated that eremanthin possessed hypoglycemic and hypolipidemic activities and hence it could be used as a drug for treating diabetes. Also, Nitin and Khosa (2009) studied the hepatoprotective activity of the ethanolic extract of the rhizomes of Costus speciosus on carbon tetrachloride poisoned rats. The extract registered a significant fall in the levels of serum glutamyl oxalacetic acid transaminase (SGOT), serum glutamyl pyruvate transaminase (SGPT), alkaline phosphatase (ALKP), serum bilirubin (SBLN) and liver inflammation supported by histopathological studies on liver, thus exhibited a significant hepatoprotective activity.

\subsection{Effect on total cholesterol, triglycerides and atherogenic index}

The effect of oral ingestion of phyllanthus and costus aqueous extracts on serum levels of total cholesterol (TC), triglycerides(TG) and atherosclerosis index of CCL4-intoxicated rats is recorded in table (3). 
Table (3):

Serum levels of total cholesterol, triglycerides and atherosclerosis index of CcL4-intoxicated and treated rats.

\begin{tabular}{|l|l|l|l|}
\hline \multicolumn{1}{|c|}{ parameters } & \multicolumn{1}{c|}{$\begin{array}{c}\text { TC } \\
\text { Groups }\end{array}$} & \multicolumn{1}{c|}{$\begin{array}{c}\text { TG } \\
(\mathrm{mg} / \mathrm{dl})\end{array}$} & \multicolumn{1}{c|}{ Al } \\
\hline Control -ve & $68.00 \pm 2.00 \mathrm{~d}$ & $50.00 \pm 1.00 \mathrm{e}$ & $0.40 \pm 0.20 \mathrm{e}$ \\
\hline Control+ve & $162.00 \pm 3.00 \mathrm{a}$ & $92.00 \pm 3.00 \mathrm{a}$ & $2.94 \pm 0.60 \mathrm{a}$ \\
\hline Phyllanthus 250/mg/kg & $89.00 \pm 4.00 \mathrm{bc}$ & $59.00 \pm 4.00 \mathrm{c}$ & $1.42 \pm 1.00 \mathrm{~b}$ \\
\hline Phyllanthus 500/mg/kg & $85.00 \pm 1.00 \mathrm{c}$ & $55.00 \pm 5.00 \mathrm{~d}$ & $1.40 \pm 0.06 \mathrm{bc}$ \\
\hline Costus 250/mg/kg & $95.00 \pm 1.00 \mathrm{~b}$ & $73.00 \pm 4.00 \mathrm{~b}$ & $1.34 \pm 0.17 \mathrm{c}$ \\
\hline Costus 500/mg/kg & $91.00 \pm 4.00 \mathrm{bc}$ & $70.00 \pm 2.00 \mathrm{bc}$ & $1.05 \pm 0.50 \mathrm{~d}$ \\
\hline
\end{tabular}

Values denote arithmetic means \pm Standard error of the mean.

Means with different letters (a, b,c,d) in the same column differ significantly at $p \leq 0.05$ using one way ANOVA test, while those with similar letters denote non-significant differences.

It is clear from data that in rats injected with C CL4 without treatment $(C+v e)$, the serum levels of total cholesterol and triglycerides were $162.00 \pm 3.00$ and $92.00 \pm 3.00 \mathrm{mg} / \mathrm{dl}$, compared to $68.00 \pm 2.00$ and $50 \pm 1.00 \mathrm{mg} / \mathrm{dl}$ in (Cve) rats $(\mathrm{C}-\mathrm{ve})$. The obtained results showed significant increase in serum levels of total cholesterol and triglycerides in rats poisoned by $\mathrm{C} C L 4$. All rats poisoned by $\mathrm{CCL} 4$ and ingestel phyllanthus and costus aqueous extract at both doses showed significant decrease in in serum levels of total cholesterol and triglycerides as compared to (C +ve) group. Regarding atherosclerosis index, there were significant increase in Al for control positive group as compared to control negative group which were $2.94 \pm 0.60$ and $0.40 \pm 0.20$, respectively. All treated groups showed significant decrease in atherogenic index when compared to control positive group. Meanwhile, rats which orally given Costus 500/mg/kg b. wt., showed the lowest decrease in $\mathrm{Al}$ as compared to all treated rats.

These results are confirmed by the findings of Qureshi et al., (2009) who reported that the aqueous extract of phyllanthus emblica also induced hypotriglyceridemia by decreasing TG levels at $0,1,2$ and 4 hours in diabetic rats $(p<0.05)$. In addition, the extract was also found to improve liver function by normalizing the activity of liver-specific enzyme alanine transaminase (ALT). Results obtained in the present work agreed with that of Mini and Kumar (1995) who tested the aqueous extract and pulp of Phyllanthus emblica for their lipid-lowering effects in hyperlipidaemic rabbits. Bavarva and Narasimhacharya (2008) concluded that Costus speciosus root extract possesses anti-hyperglycemic, antihyperlipemic and antioxidative effects, which might help in the management of diabetes and its complications.

\subsection{Effect on lipoprotein fractions (HDLc, LDLc and VLDLc)}

Data present in table (4) show the effect of oral ingestion of phyllanthus and costus aqueous extracts on the levels of lipoprotein fraction (HDLc, LDLc and VLDLC) in CCL4-intoxicated rats. 
Egypt. J. of Nutrition and Health Vol. 10 No. 1 (2015)

Table (4):

Serum levels of lipoprotein fractions (HDLc, LDLc and VLDLc) of CcL4-intoxicated and treated rats .

\begin{tabular}{|l|l|l|l|}
\hline \multirow{2}{*}{ Groups } & \multicolumn{3}{|c|}{ Lipoprotein fractions (mg/dl) } \\
\cline { 2 - 4 } & \multicolumn{1}{|c|}{ HDLc. } & \multicolumn{1}{c|}{ LDLc. } & \multicolumn{1}{c|}{ VLDLc. } \\
\hline Control -ve & $70.00 \pm 2.00 \mathrm{a}$ & $18.00 \pm 1.00 \mathrm{f}$ & $10.00 \pm 2.00 \mathrm{e}$ \\
\hline Control +ve & $31.00 \pm 2.00 \mathrm{e}$ & $72.80 \pm 2.40 \mathrm{a}$ & $18.40 \pm 1.60 \mathrm{a}$ \\
\hline Phyllanthus 250/mg/kg & $39.00 \pm 2.80 \mathrm{~cd}$ & $43.20 \pm 2.10 \mathrm{~d}$ & $11.80 \pm 2.70 \mathrm{c}$ \\
\hline Phyllanthus 500/mg/kg & $35.00 \pm 3.00 \mathrm{~d}$ & $38.00 \pm 4.00 \mathrm{e}$ & $11.00 \pm 2.00 \mathrm{~cd}$ \\
\hline Costus 250/mg/kg & $50.00 \pm 2.00 \mathrm{bc}$ & $52.40 \pm 16.80 \mathrm{~b}$ & $14.60 \pm 3.20 \mathrm{~b}$ \\
\hline Costus 500/mg/kg & $55.00 \pm 3.00 \mathrm{~b}$ & $44.00 \pm 3.00 \mathrm{c}$ & $14.00 \pm 3.00 \mathrm{bc}$ \\
\hline
\end{tabular}

Values denote arithmetic means \pm Standard error of the mean.

Means with different letters (a, b,c,d) in the same column different significantly at $p \leq 0.05$ using one way ANOVA test, while those with similar letters denote non-significant difference.

It could be noticed that in rats injected with CcL4 without treatment $(C+v e)$, the serum levels of HDLc, LDLc and VLDLc were $31.00 \pm 2.00,72.80 \pm 2.40$ and $18.40 \pm 1.60 \mathrm{mg} / \mathrm{dl}$, respectively, while in $(\mathrm{C}-\mathrm{ve})$ rats, the serum levels of the previously mentioned lipoprotein fractions were $70.00 \pm 2.00,18.00 \pm 1.00$ and $10.00 \pm 2.00 \mathrm{mg} / \mathrm{dl}$, respectively. These findings denote that there were significant decrease in HDLc but significant increase in LDLc and VLDLc lipoprotein fractions in the serum of rats poisoned by CcL4 without treatment as compared with the control -ve rats. All rats poisoned by $\mathrm{CCL} 4$ and given phyllanthus and costus aqueous extract at both doses showed significant increase in (HDL-c) and significant decrease in low and very low density lipoprotein (LDLc and VLDLC) compared with the control +ve group.

Our results support that of by Jayasri, et al., (2009) who evaluated the antioxidant activity of the plant Costus pictus, where leaves and rhizomes of $C$. pictus showed good antioxidant activity. Their study suggested that $C$. pictus plant could be used as a potent source of natural antioxidants.

\subsection{Effect on kidney function(Creatinine, Urea and Uric acid)}

Table (5) shows the effect of oral ingestion with phyllanthus and costus aqueous extracts on kidney function(Creatinine, Urea and Uric acid) in CcL4-intoxicated and treated group. 
Table (5):

Serum Creatinine, Urea and Uric acid in CcL4-intoxicated and treated rats.

\begin{tabular}{|l|l|l|l|}
\hline \multicolumn{1}{|c|}{ Parameters } & \multicolumn{1}{|c|}{ Creatinine $(\mathrm{U} / \mathrm{L})$} & \multicolumn{1}{c|}{ Urea $(\mathrm{U} / \mathrm{L})$} & \multicolumn{1}{c|}{ Uric Acid $(\mathrm{U} / \mathrm{L})$} \\
\hline Control -ve & $0.32 \pm 0.01 \mathrm{e}$ & $21.10 \pm 2.50 \mathrm{e}$ & $1.36 \pm 0.94 \mathrm{~d}$ \\
\hline Control+ve & $0.70 \pm 0.20 \mathrm{a}$ & $42.50 \pm 2.20 \mathrm{a}$ & $5.70 \pm 0.80 \mathrm{a}$ \\
\hline Phyllanthus $250 / \mathrm{mg} / \mathrm{kg}$ & $0.49 \pm 0.04 \mathrm{~b}$ & $28.40 \pm 3.95 \mathrm{bc}$ & $1.42 \pm 0.58 \mathrm{c}$ \\
\hline Phyllanthus $500 / \mathrm{mg} / \mathrm{kg}$ & $0.35 \pm 0.06 \mathrm{~d}$ & $22.20 \pm 1.70 \mathrm{de}$ & $1.37 \pm 0.08 \mathrm{~cd}$ \\
\hline Costus $250 / \mathrm{mg} / \mathrm{kg}$ & $0.39 \pm 0.03 \mathrm{c}$ & $31.50 \pm 2.40 \mathrm{~b}$ & $1.53 \pm 0.33 \mathrm{~b}$ \\
\hline Costus $500 / \mathrm{mg} / \mathrm{kg}$ & $0.42 \pm 0.03 \mathrm{bc}$ & $26.10 \pm 1.00 \mathrm{c}$ & $1.49 \pm 0.19 \mathrm{bc}$ \\
\hline
\end{tabular}

Values denote arithmetic means \pm Standard error of the mean.

Means with different letters (a, b,c,d) in the same column differ significantly at $p \leq 0.05$ using one way ANOVA test, while those with similar letters denote non-significant difference.

Serum levels of creatinine, urea and uric acid were $0.70 \pm 0.20,42.5 \pm 2.20$ and $5.70 \pm 0.80 \mathrm{U} / \mathrm{L}$, respectively in rats intoxicated with CCL4 without treatment., while in (C -ve) rats, the serum levels of the mentioned previously parameters were $0.32 \pm 0.01,21.10 \pm 2.50$ and $1.36 \pm 0.94 \mathrm{U} / \mathrm{L}$, respectively. These findings denote that there were significant increases in serum levels of creatinine, urea and uric acid of rats poisoned by CcL4 (C +ve) as compared to $(C-v e)$ normal rats $p<0.05$. phyllanthus aqueous extract at a dose of $500 / \mathrm{mg} / \mathrm{kg} \mathrm{b}$. wt., group showed the highest significant improvement in creatinine, urea and uric acid when compared to other tested groups (table5). 
3. Histopathological results

\begin{tabular}{|c|c|}
\hline $\begin{array}{l}\text { Photo. (1): Normal histological structure of } \\
\text { hepatic lobule }(H \& E \times 400) \text {. }\end{array}$ & $\begin{array}{l}\text { Photo. (2): Liver of rat from ( } \mathrm{C}+\mathrm{ve} \text { group) showing } \\
\text { fibroplasia in the portal triad and necrosis of sporadic } \\
\text { hepatocytes and sinusoidal leukocytosis (H \& E X 400). }\end{array}$ \\
\hline 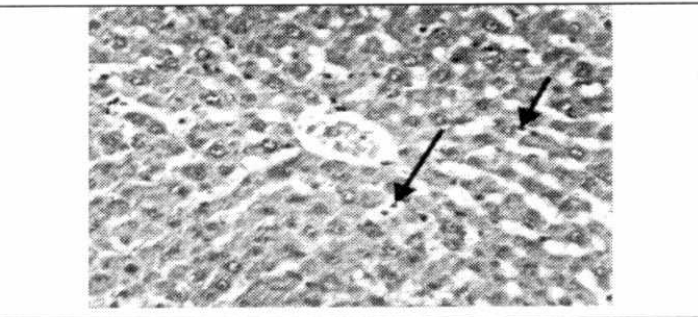 & 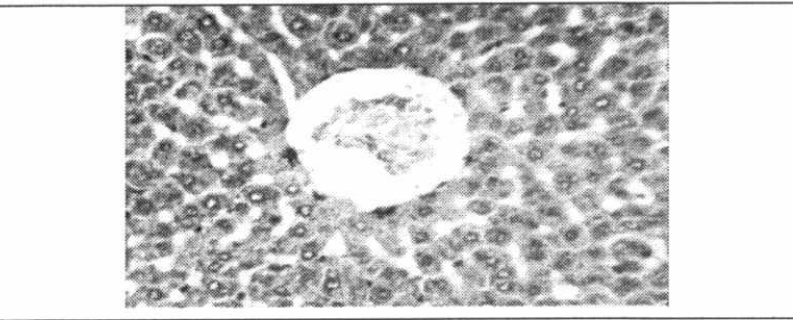 \\
\hline $\begin{array}{l}\text { Photo. (3): Liver of rat from group of phyllanthus } \\
250 / \mathrm{mg} / \mathrm{kg} \mathrm{b} \text { bt., showing Kupffer cells activation } \\
\text { and leucocytes in hepatic sinusoids (H \& E X } \\
\text { 400). }\end{array}$ & $\begin{array}{l}\text { Photo. (4): Liver of rat from group of phyllanthus } \\
500 / \mathrm{mg} / \mathrm{kg} \text { b. wt., showing no histopathological } \\
\text { abnormalitie. (H \& EX 400). }\end{array}$ \\
\hline 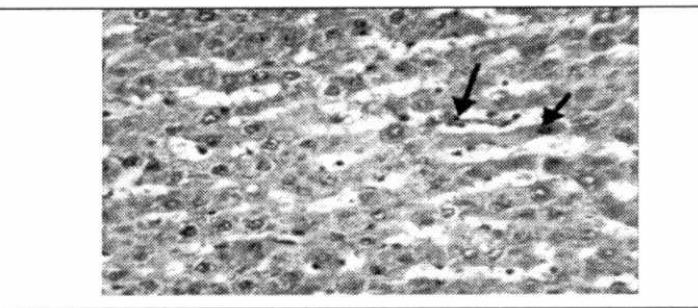 & 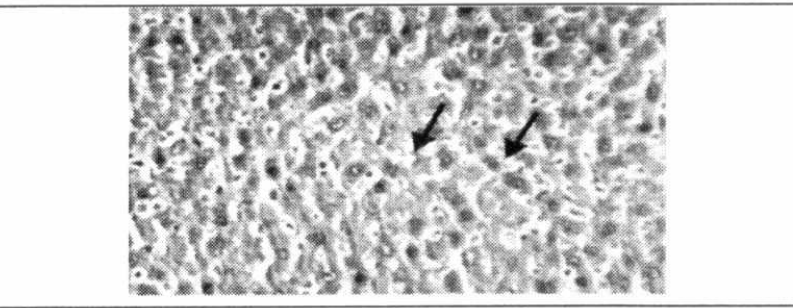 \\
\hline $\begin{array}{l}\text { Photo. (5): Liver of rat from group of costus } 250 \\
\mathrm{mg} / \mathrm{kg} \text { b. wt., showing necrosis of sporadic } \\
\text { hepatocytes and sinusoidal leukocytosis. (H \& E } \\
\text { X 400). }\end{array}$ & $\begin{array}{l}\text { Photo. (6): Liver of rat from group of costus } 500 \mathrm{mg} / \mathrm{kg} \\
\text { b. wt., showing congestion of hepatic sinusoids. (H \& E } \\
\times 400 \text { ). }\end{array}$ \\
\hline
\end{tabular}

\section{Conclusion}

According to the results, phyllanthus and costus aqueous extracts could be tried on intoxicated patients to improve liver \&kidney function . 


\section{References}

Bavarva, J. H. and Narasimhacharya, A. V. R. L.(2008):

Antihyperglycemic and hypolipidemic effects of Costus speciosus in alloxan induced diabetic rats. J. of Phytotherapy Research; 2008. 22(5):620-626.

Campbell,J.A. (1963):

Methodology of Protein Evaluation RAG-Nutr.,Document R.10Ed.,37 . June Meeting New York.

Champman,D.G.;Gastilla, R. AND Cambell,J.A.(1959):

Evaluation of protein in food.L.A. method for the determination of protein efficiency ratio. Can. J.Biochem. Phosiol.,37:679-686.

Charoenteeraboon, J.; Ngamkitidechakul, C.; Soonthornchareonnon, N.; Jaijoy, K. and Sireeratawong, S.(2010): Antioxidant activities of the standardized water extract from fruit of Phyllanthus emblica Linn. J. of Science and Technology; 2010. 32(6):599-604.

Dickerson, J. W. and Lee, H. A. (1988):

"Nutrition in the Clinical Management of Disease". Second edition. Edward Arnold.

Drury, R. A. and Wallington, E. A. (1967):

"Carlton's Histological Technique". $5^{\text {th }}$ Ed. Oxford Univ.

Eliza, J.; Daisy, P.; Ignacimuthu, S. and Duraipandiyan, V.(2009):

Antidiabetic and antilipidemic effect of eremanthin from Costus speciosus (Koen.)Sm., in STZ-induced diabetic rats. J. of Chemico-Biological Interactions; . 182(1):67-72.

Filomena, M.; Paola, V.; Daniela, A.; Barbara, R.; Vincenzo, F. and Nicola, C.(2008): Foods and liver health. Volume 29, Issues 1-2, Pages 144-150.

Gordon, T. and Amer, M. ( 1977 ):

"Determination of HDL". J. of Med., $62: 707$.

Gulati, R. K.; Agarwal, S. and Agrawal, S. S.(1995):

Hepatoprotective studies on Phyllanthus emblica Linn. and quercetin.Indian J. of Exp Biol. 33(4):261-8.

Hegsted, D.; Mills, R. and Perkins, E. (1941):

Salt mixture. J. of Biol. Chem., 138: 459.

Henry, R. J.(1974): Clinical Chemistry Principal and Techniques. $2^{\text {nd }}$ Ed. Harper and Publisher. New York.

Jacobs, N. J. and Van-Denmark, P.J. (1960) :

"Determination of triglycerides" . J. of Arch. Biochem . Biophys., $88: 250-255$

Jayasekhar, P.; Mohanan, P. V. and Rahinam, K. (1997):

"Hepatoprotective activity of ethyl acetate extract of Acacia catechu". Indian. J. of Pharmacology, 29: 426-428. 


\section{Egypt. J. of Nutrition and Health Vol. 10 No. 1 (2015)}

Jayasri, M. A.; Lazar M. and Radha, A.(2009):

A report on the antioxidant activity of leaves and rhizomes of Costus pictus D. Don. International Journal of Integrative Biology; 2009. 5(1):20-26.

Lemhadri A.; Zeggwagh, N. A.; Maghrani, M.; Jouad, H. and Eddouks, M.(2004):

Inhibition of endogenous glucose production accounts for hypoglycaemic effect of Spergularia purpurea in diabetic mice. J. of Ethnopharmacology, 92(2-3): 251-256.

Mini, K. P. and Kumar, N. G. (1995):

Effect of Emblica officinalis [Phyllanthus emblica] on plasma cholesterol and triglyceride levels in rabbits. Journal of Veterinary and Animal Sciences; 1995. 26(2):85-87.

Nitin, V. and Khosa, R. L.(2009):

Evaluation of protective effects of ethanolic extract of Costus speciosus (Koenig) Sm. rhizomes on carbon tetrachloride induced hepatotoxicity in rats. J. of Natural Product Radiance. 8(2):123-126.

Passmore, R. and Eastwood, M. A. (1986):

"Human Nutrition and Dietetics". Eight edition. Longman Group UK LTD. Churchill Livingstone.

Pattn, C. J. and Croush, S. R.(1977):

Enzymatic Determination of Urea. J. of Anal. Chem., (230): 464-469.

Qureshi, S. A.; Warda, A. and Viqar, S.(2009):

The effect of Phyllantus emblica Linn on type-Il diabetes, triglycerides and liver-specific enzyme. Pakistan Journal of Nutrition; 2009. 8(2):125-128.

Ratliff, C. R. and Hall, F. (1973):

A New Method for Direct Colorimetric Determination of Serum Cholesterol. Lab. Manual of Clinical Biochemistry. Scoot and White Memorial Hospital Publications. Temple. TX. USA.

Reitman, S. and Frankel ( 1957 ):

"Colorimetric method for aspartate and alanine aminotransferase". Am. J. of Clin. Path., 28:26.

Roy, S. E. (1970):

"Colorimetric determination of serum alkaline phosphatase". Clin. Chem., 16:431-432

Schultz, A.(1984):

Uric Kaplan A et al., Clin Chem. Mosby Co. St. Louis Toronto. Princeton, 1261, 1266 and 418.

Snedecor, G. W. and Cochran, W. G. ( 1967 ) :

"Statistical Methods". 6th Ed. Iowa State University Press. Ames. Lowa. USA.

Sultana, S.; Ahmad, S.; Khan, N. and Jahangir, T.(2005):

Effect of Emblica officinalis (Gaertn) on $\mathrm{CCl} 4$ induced hepatic toxicity and DNA synthesis in Wistar rats. Indian J. of Exp Biol. 2005 May;43(5):430-6.

Ukpabi C. F., Agbafor K. N., Ndukwe O. K., Agwu, A. and Nwachukwu, S. N.,(2012):

"Phytochemical Composition of Costus Afer Extract and Its Alleviation of Carbon Tetrachloride - induced Hepatic Oxidative Stress and Toxicity", International Journal of Modern Botany, Vol. 2 No. 5, pp. 120-126. 


\title{
التأثيرات العلاجية المحتملة للمستخلصات المائية للأملج والقسط الهندي على الفئران المصابة بالتسمم الكبدي باستخدام رابع كلوريد الكربون
}

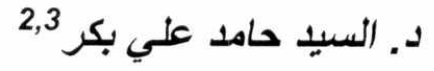 \\ د. منسى ابرا هيم محمد نـجا 1 \\ 1 كلية التربية النوعية ـ قسم الاقتصاد المنزلى (تغذية و علوم أطعمة) - جامعة المنوفية - مصر .

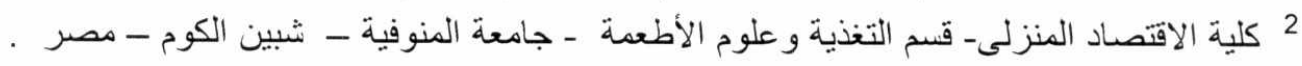 \\ 3 قسم التغذية الاكلينيكية- كلية العلوم الطبية التطبيقية- جامعة أم القرى- المملكة العربية السعودية. \\ المستخلص العربي
}

خلفية البحث: تلف الكبد المزمن هو أكثر الأمر اض شيوعا في جميع أنحاء العالم، وتتميز عملية الالتهاب والتليف الذي يؤدي التي

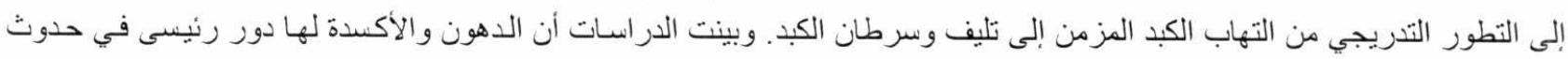

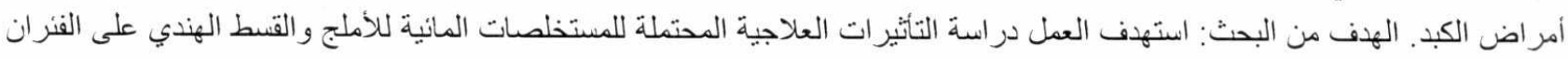

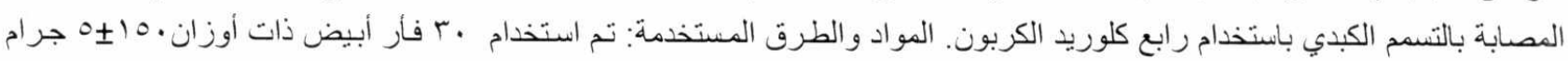

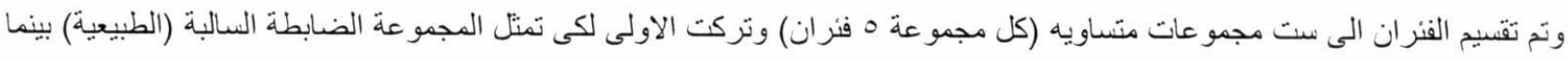

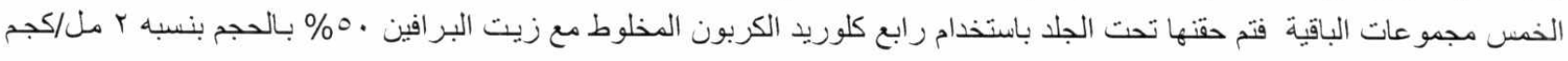

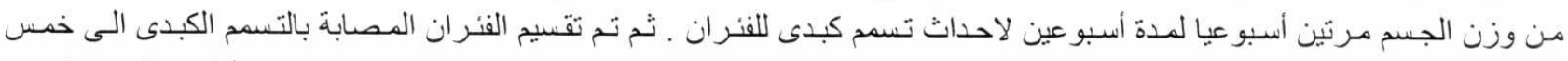

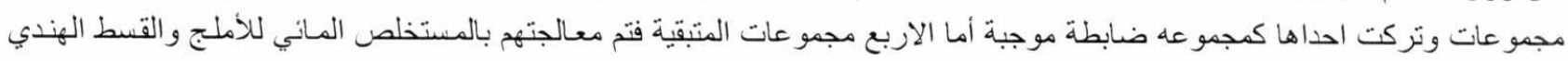

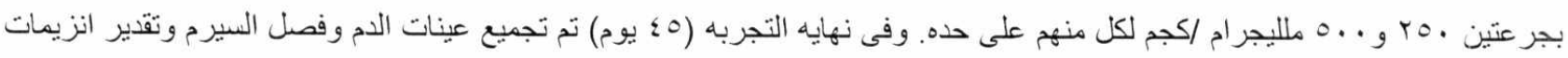

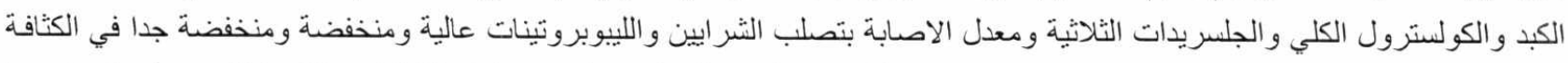

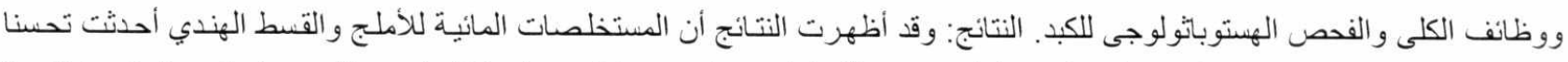

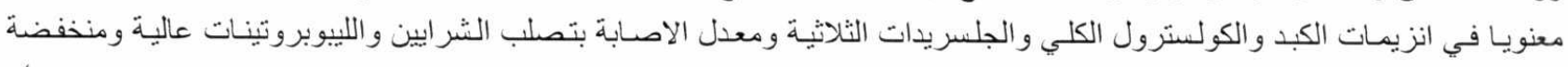

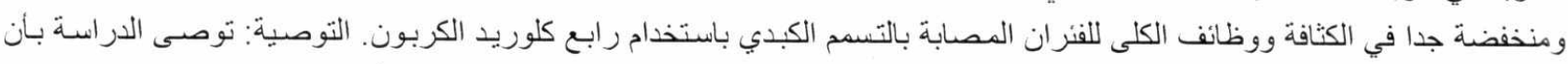

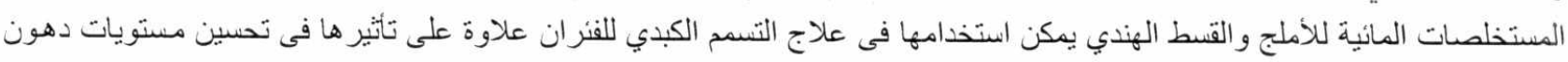
الدم وانزيمات الكلى.

الكلمات المفتحية: التسمم الكبدي- الأملج- القسط الهندي ـ المستخلصات المائية. 